\title{
Antioxidant potential, cytotoxic activity and total phenolic content of Alpinia pahangensis rhizomes
}

\author{
Chung-Weng Phang, Sri Nurestri Abd Malek* and Halijah Ibrahim
}

\begin{abstract}
Background: Alpinia pahangensis, a wild ginger distributed in the lowlands of Pahang, Malaysia, is used by the locals to treat flatulence. In this study, the antioxidant and cytotoxic activities of the crude aqueous methanol and fractionated extracts of Alpinia pahangensis against five different cancer and one normal cell lines were investigated. The total phenolic content of each extract and its fractions were also quantified. This is the first report on the antioxidant and cytotoxic activities of Alpinia pahangensis extract.
\end{abstract}

Methods: In the current study, the crude methanol and fractionated extract of the rhizomes of Alpinia pahangensis were investigated for their antioxidant activity using four different assays namely, the DPPH scavenging activity, superoxide anion scavenging, $\beta$-carotene bleaching and reducing power assays whilst their phenolic contents were measured by the Folin-Ciocalteu's method.

In vitro neutral red cytotoxicity assay was employed to evaluate the cytotoxic activity against five different cancer cell lines, colon cancer (HCT 116 and HT-29), cervical cancer (Ca Ski), breast cancer (MCF7) and lung cancer (A549) cell lines, and one normal cell line (MRC-5). The extract that showed high cytotoxic activity was further investigated for its chemical constituents by GC-MS (gas chromatography-mass spectrometry) analysis.

Results: The ethyl acetate fraction showed the strongest DPPH radical scavenging $(0.35 \pm 0.094 \mathrm{mg} / \mathrm{ml})$ and SOD activities $(51.77 \pm 4.9 \%)$ whilst the methanol extract showed the highest reducing power and also the strongest antioxidant activity in the $\beta$-carotene bleaching assays in comparison to other fractions. The highest phenolic content was found in the ethyl acetate fraction, followed by the crude methanol extract, hexane and water fractions. The results showed a positive correlation between total phenolic content with DPPH radical scavenging capacities and SOD activities. The hexane fraction showed potent cytotoxic effect against KB, Ca Ski and HCT 116 cell lines with $I C_{50}$ of $5.8 \pm 0.1$ and $9.1 \pm 2.0 \mathrm{ug} / \mathrm{ml}$, respectively. The major components of hexane fraction analysed by GC-MS analysis were mostly methyl esters.

Conclusions: The current study suggests that the methanol extract and ethyl acetate fraction of $A$. pahangensis is a potential source of natural antioxidant for protective as well as prevention of life-threatening diseases. The hexane fraction of A. pahangensis may have the potential to be developed into therapeutic option for treating cancer.

Keywords: Alpinia pahangensis, Antioxidant, Phenolic content, Cytotoxic activity

\footnotetext{
* Correspondence: srimalek@um.edu.my

Institute of Biological Sciences, Faculty of Science, University of Malaya, Kuala Lumpur, 50603, Malaysia
} 


\section{Background}

Alpinia species, from the Zingiberaceae family have been extensively studied for their chemical and biological properties [1]. Based on the ethnobotanical studies, many species of this genus have been used in traditional medicine, and in the preparations and flavorings of food in many Asian countries. Among the Alpinia species, the rhizomes of Alpinia galanga have been widely used as spice and in the treatment of stomachic in China and Thailand; coughs, asthma, bronchitis, headache, inflammation, rheumatoid arthritis and colic in Malaysia [2,3]. One wild species, Alpinia mutica has been used to treat stomach upset by natives and it has also been reported to show good antioxidant and cytotoxic anticancer properties [4]. A few novel compounds isolated from the species of Alpinia had been found to have anti-cancer, antiinflammatory, anti-spasmodic, anti-ulcerogenic, neuroprotective, analgesic, hepatoprotective and cardioprotective properties [5]. Due to its wide therapeutic values, it is of great interest to conduct more studies on the unexplored species from this genus which may possess medicinal properties, yet has not been fully studied. In this endeavour, Alpinia pahangensis was thus selected for investigation.

Alpinia pahangensis, a wild ginger, occcuring less common in the genus, is a perennial plant distributed in the lowlands of Pahang, Malaysia. The rhizomes of $A$. pahangensis have been used by tribal natives for relieving flatulence. However, there is a limited study on the biological activity of the $A$. pahangensis. A recent report by Awang et al. [6] showed that the essential oil extracted from the rhizomes and leaves of Alpinia pahangensis had good antimicrobial activity against Staphylococcus aureus strains and selected fungi.

Free radicals produced in our body due to aerobic respiration and substrate oxidation, can cause oxidative stress which may contribute to the development of several diseases including cancer, Alzheimer's disease, aging, diabetes, Parkinson disease and atherosclerosis [7-13]. Overproduction of free radicals in our bodies may be increasing due to pollution and other external factors, and their removal by our antioxidant systems may be lower than before due to a number of factors related to our lifestyle among others. Oxidative stress causes serious damage to important cellular macromolecules such as protein and DNA. However, the production of free radicals can be balanced by antioxidant actions of endogenous enzymes as well as natural and synthetic antioxidants [14,15]. Antioxidants exert its action through several mechanisms including prevention of chain initiation, chelating of transition metal ion catalysts, decomposition of peroxidases, prevention of continued hydrogen abstraction and radical scavenging [16].
These deleterious effects of free radicals have drawn the attentions of scientists to the importance of antioxidants in prevention and treatment of diseases [17]. Thus, there has been increasing interest in finding natural dietderived antioxidant to prevent oxidative damage $[18,19]$. Thus many studies have been carried out on natural sources to unravel the components which possess antioxidant properties and with low cytotoxicities [20]. Natural antioxidants are generally more desirable for consumption than the synthetic one such as butylated hydroxyanisole (BHA) which was reported to be carcinogenic to humans [21]. Recently, many studies have been carried out on the antioxidant properties of phenolic compounds which have aroused increasing interest in the isolation of such compounds present in the plants [22].

Cancer is a genetic disease, which is mainly driven by genetic instability, including changes in oncogenes and tumor suppressor genes which leads to the expression of abnormal proteins involved in the stimulation of cell proliferation and survival [23,24]. A large body of evidences have shown that free radicals have been implicated in the development of cancer in humans [25,26]. One example of the free radicals, is the hydroxyl radical which can cause genetic mutation by forming adduct with guanine to form hydroxylated bases of DNA (8 hydroxyl-2'-deoxyguanosine) causing transversions of GC (guanine-cytosine) to TA (thymine-adenine) [27,28]. Epidemiologic studies have also shown that cancer may be due to several factors such as exposure to environmental carcinogenic agents, lifestyle (tobacco and alcohol consumption), nutritional habit and infectious agents [29-32]. These factors can initiate and promote carcinogenesis which may progress to cancer.

To the best of our knowledge, there is no antioxidant and cytotoxic investigation on extracts of this species. Thus, this paper reports the antioxidant and cytotoxic activities of the crude aqueous methanol and fractionated extracts of the rhizomes of Alpinia pahangensis and to determine the phenolic content. This study also aims to correlate the phenolic content of the crude and fractionated extracts with its antioxidant properties. The active extract was further subjected to gas chromatography-mass spectrometry (GC-MS) analysis for identification of the components present in the extract.

\section{Methods}

\section{Sample collection}

The rhizomes of Alpinia pahangensis were collected from Pahang, Malaysia. This species was authenticated by Professor Dr Halijah Ibrahim, from Faculty of Science, University of Malaya and a voucher specimen (No. KLU 46177) deposited in the university herbarium. 


\section{Reagents and chemicals}

Butylated hydroxyanisole (BHA), ascorbic acid, FolinCiocalteu's phenol reagent, $\beta$-carotene, linoleic acid, Tween 80, gallic acid and 2,2-diphenyl-1-picrylhydrazyl $(\mathrm{DPPH})$, potassium ferricyanide were acquired from Sigma-Aldrich. Methanol, hexane, ethyl acetate and trichloroacetic acid were obtained from Merck. All solvents were purchased in analytical grade.

\section{Human cell line and culture medium}

The cell lines were purchased from the American Tissue Culture Collection (ATCC, USA). The human cell lines used were nasopharyngeal epidermoid carcinoma cell line (KB), cervical carcinoma cell line (Ca Ski), colon adenocarcinoma cell line (HT-29), colon carcinoma cell line (HCT 116), lung adenocarcinoma epithelial cell line (A549), hormone-dependent breast carcinoma cell line (MCF7) and non-cancer human fibroblast cell line (MRC5). The cells were propagated using the following growth media: RPMI (Sigma) for MCF7, Ca Ski, HT-29 cell lines, McCOY's (Sigma) for HCT 116 cell line, and EMEM (Sigma) for MRC5 and KB cell lines, supplemented with $10 \%$ foetal bovine serum (PAA Lab, Austria), $100 \mu \mathrm{g} / \mathrm{ml}$ penicillin/streptomycin (PAA Lab, Austria) and $50 \mu \mathrm{g} / \mathrm{ml}$ of fungizone (PAA Lab, Austria). The cells were given new media every 2 to 3 days until $90 \%$ confluency. The viability of the cells was checked before and after treatment by the tryphan blue exclusion dye method. Frozen cell stocks were stored in liquid nitrogen $\left(-196^{\circ} \mathrm{C}\right)$ prior to use.

\section{Extraction and fractionation}

The dried, ground rhizomes of Alpinia pahangensis (200 g) were soaked in $80 \%$ aqueous methanol ( $3 \mathrm{~L}$ ) for 3 days at room temperature. The solvent-containing extract was then filtered and the filtrate obtained was evaporated using a rotary evaporator at $40^{\circ} \mathrm{C}$ under vacuum to give the crude methanol extract ( $31.19 \mathrm{~g}, 15.60 \%$ based on the weight of dried, ground rhizomes). The crude methanol extract $(31.19 \mathrm{~g})$ was extracted with hexane $(500 \mathrm{~mL})$ and repeated three times (each time using $500 \mathrm{~mL}$ of hexane). The hexane-containing extracts were combined and concentrated in vacuo to give the hexane fraction $(1.87 \mathrm{~g}, 6.00 \%)$. The hexane insoluble residue was further partitioned using ethyl acetate and water $(500: 500 \mathrm{~mL})$ to give the ethyl acetate fraction $(2.70 \mathrm{~g}$, $8.66 \%)$ and the water fraction (24.43 g, 78.33\%). The yield of crude methanol extract was calculated based on the weight of the dried, ground rhizomes whereas the yields of the fractions were calculated based on the weight of the crude methanol extract.

\section{Determination of total phenolic content}

The total phenolic content was determined according to the Folin-Ciocalteu method as described by Phang et al
[33]. The crude methanolic extract, hexane fraction, ethyl acetate fraction and positive control (BHA and ascorbic acid) were dissolved in methanol while water fraction was dissolved in distilled water. The total phenolic content $(\mathrm{mg} /$ $\mathrm{g}$ of plant extract) in the crude aqueous methanol extract and its fractions expressed in gallic acid equivalents (GAE). Mean values were calculated from three measurement.

\section{DPPH radical scavenging assay}

The DPPH radical scavenging activity was determined using the method as described by Phang et al. [33]. An aliquot of extract of different concentrations were mixed with $0.8 \%$ of DPPH solution $(0.02 \mathrm{~mL})$ in methanol. Reaction mixtures were mixed well and incubated at room temperature for 30 minutes. Absorbance was read at $520 \mathrm{~nm}$ using spectrophotometer (UV-2450 Shimadzu). Methanol was used as blank and DPPH solution without addition of extract was used as control. BHA and ascorbic acid were used as standards. The percentage inhibition activity was calculated as $\left[\left(A_{0}-A_{1}\right) / A_{0}\right] \times 100$, where $A_{0}$ was the absorbance of the control, and $A_{1}$ was the absorbance of the extract/standard. The $\mathrm{IC}_{50}$ value was determined by interpolation from non-linear regression of plot of percentage of inhibiton against the concentration of extracts, which is defined as the amount of extract needed to scavenge $50 \%$ of DPPH radicals.

\section{$\beta$-carotene bleaching assay}

The antioxidant activity of the extract was determined according to the method of Phang et al. [33]. A reagent mixture was prepared containing of $\beta$-carotene $(0.2 \mathrm{mg} / \mathrm{ml}$ in chloroform), linoleic acid $(0.02 \mathrm{ml})$ and Tween 80 $(0.2 \mathrm{ml})$. The reagent mixture was then transferred into a round bottom flask and the chloroform was removed using rotary evaporator. Oxygenated water $(50 \mathrm{ml})$ was then added into the flask and shaken vigorously. Aliquots $(5 \mathrm{ml})$ of the emulsion were transferred into test tubes containing $0.2 \mathrm{ml}$ of extracts with different concentrations $(4,8,16$ and $20 \mathrm{mg} / \mathrm{ml}$ ). After the emulsion was added into each test tube, the absorbance at zero time was measured immediately at $470 \mathrm{~nm}$ using a spectrophotometer (Genesys). The test tubes were then incubated at $50^{\circ} \mathrm{C}$ and the absorbance of each tube was measured again at time intervals of 20 minutes for 2 hours. The blank is the flask that is devoid of $\beta$-carotene whilst methanol is used as negative control. BHA was used as positive control.

The degradation rate of $\beta$-carotene (R) was calculated according to the equation below based on that described by Al-Saikhan et al. [34]:

$$
\mathrm{R}=\frac{\ln \left(\mathrm{A}_{0} / \mathrm{A}_{\mathrm{t}}\right)}{\mathrm{t}}
$$

where $\ln$ is natural logarithm, $A_{0}$ is absorbance at time $0, A_{t}$ is absorbance at time $t$, and $t$ is $20,40,60$, 
80,100 or 120 minutes. The antioxidant activity (\%) was calculated in terms of percentage inhibition relative to the control, using the equation below:

$$
\text { Antioxidant activity }(\%)=\left(\frac{\mathrm{R}_{\text {control }}-\mathrm{R}_{\text {sample }}}{\mathrm{R}_{\text {control }}}\right) \times 100 \%
$$

\section{Reducing power assay}

The reducing power was determined by the method of Murugan and lyer [35]. Different concentration of extracts $(1,0.5,0.25,0.125,0.0625,0.03125,0.015625 \mathrm{mg} / \mathrm{ml})$ dissolved in $1.0 \mathrm{~mL}$ of methanol, were mixed with $200 \mu \mathrm{L}$ of $0.2 \mathrm{M}$ phosphate buffer $(\mathrm{pH}$ 6.6) and $200 \mu \mathrm{L}$ of $1 \%(\mathrm{w} / \mathrm{v})$ solution of potassium ferricyanide. The mixture was incubated at $50^{\circ} \mathrm{C}$ for $30 \mathrm{mi}-$ nutes. Then, $200 \mu \mathrm{L}$ of $10 \%(\mathrm{w} / \mathrm{v})$ trichloroacetic acid solution was added after the mixture had cooled down. Aliquot of the upper layer $(200 \mu \mathrm{L})$ was transferred to a 96 well plate and $20 \mu \mathrm{L}$ of $0.1 \%(\mathrm{w} / \mathrm{v})$ solution of ferric chloride was added. Absorbance of the reaction mixture was read at $620 \mathrm{~nm}$ in a plate reader (BioTek). Mean values from three measurement were taken. BHA and ascorbic acid were used as standards and the reaction mixture with methanol instead of the extract was used as (negative) control. The total reducing activity was determined by using formula:

Total reducing activity $(\%)=1-\left(\mathrm{A}_{\mathrm{c}} / \mathrm{A}_{\mathrm{t}}\right) \times 100$

Where:

$\mathrm{A}_{\mathrm{c}}=$ Absorbance of control (reaction mixture with methanol instead of extract).

$A_{t}=$ Absorbance with extracts/standards.

\section{Superoxide anion scavenging activity assay}

The enzymatic antioxidant activity of the extract was determined using the SOD assay Kit-WST purchased from Sigma-Aldrich. The concentration of the extract/ fractions and standards used was $5 \mathrm{mg} / \mathrm{ml}$. This assay was done using 96 wells microtiter plate. Sample solution $(20 \mu \mathrm{l})$ was added to sample well and blank 2 well, and $20 \mu \mathrm{l}$ of $\mathrm{ddH}_{2} \mathrm{O}$ (doubled distilled water) was added to blank 1 and blank 3 wells. WST working solution $(20 \mu \mathrm{l})$ was then added to each well and $20 \mu \mathrm{l}$ of enzyme working solution was added to the sample well and the blank 1 well. The resultant mixtures were then mixed thoroughly. The plate was then incubated at $37^{\circ} \mathrm{C}$ for $20 \mathrm{~min}$.

After incubation, the absorbance was read at $450 \mathrm{~nm}$ using an Elisa microplate reader. The superoxide anion scavenging activity was calculated according to the following equation:

$$
\begin{aligned}
& \text { SOD activity (inhibiton rate } \%) \\
& =\left\{\left[\left(\mathrm{A}_{\text {blank1 }}-\mathrm{A}_{\text {blank3 }}\right)-\left(\mathrm{A}_{\text {sample }}-\mathrm{A}_{\text {blank2 }}\right)\right]\right. \\
& \left./\left(\mathrm{A}_{\text {blank1 }}-\mathrm{A}_{\text {blank } 3}\right)\right\} \times 100
\end{aligned}
$$

Where $A_{\text {blank1 }}, A_{\text {blank2 }}, A_{\text {blank3 }}$ and $A_{\text {sample }}$ are absorbances of blank1, blank2, blank3, and sample wells. One unit of SOD activity was defined as the amount of enzyme having a $50 \%$ inhibitory effect on WST-1. The experiment was conducted in triplicates.

\section{In vitro neutral red cytotoxicity assay}

The Neutral Red cytotoxicity assay used was based on the method described by Borenfreund and Puerner [36] with some modifications. Briefly, confluent cells were detached from the flask by incubating in $1 \mathrm{ml}$ of $0.25 \%$ Trypsin-EDTA solution and were then seeded into sterile 96 wells microtiter plates (Nunc) at a density of $1 \times$ $10^{4}$ cells per well. The cells were allowed to attach for 24 hours in a humidified $5 \% \mathrm{CO}_{2}$ incubator at $37^{\circ} \mathrm{C}$ and maintained with growth medium. After 24 hours, the cells were treated with different concentration range of extracts $(1,10,50,100 \mathrm{ug} / \mathrm{ml})$ for 72 hours. Doxorubicin was used as the positive control. The wells containing untreated cells were used as the negative control. At the end of the incubation period, the cells were incubated with media containing $50 \mu \mathrm{g} / \mathrm{ml}$ of Neutral Red for 3 hours. After 3 hours, the absorbance of dye eluted from viable cells was measured at $540 \mathrm{~nm}$ using a spectrophotometer Elisa plate reader (Molecular Devices EMax). The assay was carried out in triplicates. The concentration of extract which causes $50 \%$ inhibition or cell death is the $1 \mathrm{C}_{50} . \mathrm{IC}_{50}$ value for each extract was extrapolated from the graph plotted using the OD values obtained. The percentage of inhibition of each of the test samples was calculated according to the following formula:

$$
\% \text { of inhibition }=\frac{\mathrm{OD}_{\text {control }}-\mathrm{OD}_{\text {sample }}}{\mathrm{OD}_{\text {control }}} \times 100 \%
$$

Where OD control: Absorbance of negative control and OD sample: Absorbance of sample.

\section{Identification of the components}

The GC-MS analysis was carried out using a Agilent Technologies 6980 N (United States) gas chromatography equipped with a 5979 Mass Selective Detector (70 eV direct inlet) and a HP-5 ms (5\% phenylmethylsiloxane) capillary column $(30 \mathrm{~m} \times 25 \mathrm{~mm} \times 0.25 \mathrm{~mm}$ film thickness) initially set at $100^{\circ} \mathrm{C}$, then increased to $300^{\circ} \mathrm{C}$ and held for 10 minutes at ramp rate of $3^{\circ} \mathrm{C}$ per min using helium as the carrier gas at flow rate of $1 \mathrm{ml} \mathrm{min}^{-1}$. The 
total ion chromatogram obtained was autointegrated by Chemstation, and the components were identified by comparison with the accompanying mass spectral database (NIST 05 Mass Spectral Library).

\section{Statistical analysis}

Data are expressed as mean \pm SD of triplicates. Analysis of variance was used to determine any significant differences between groups using STATGRAPHICS Plus software (version 3.0, Statistical Graphics Corp., Princeton, NJ, USA). Statistical significance was accepted at $\mathrm{p}<0.05$. Duncan's multiple range tests (DMRT) were used to determine the significant differences between groups.

\section{Results and discussion}

\section{Amount of phenolic compounds in Alpinia pahangensis} extract

Phenolic compounds are secondary metabolites that are derived from the pentose phosphate, shikimate and phenylpropanoid pathways in plants [37]. Phenolic compounds have been recognized to possess high antioxidant properties. The antioxidant activity of phenolic compounds is mainly due to their redox properties which allow them to act as radical scavengers, metal chelators, reducing agents, hydrogen donors, and singlet oxygen quenchers [38,39]. Thus, it is essential to evaluate the effect of the total phenolic content on the antioxidant activity of the extract and its fractions. Selection of solvents for extraction and fractionation is important in order to obtain desirable phenolic constituents. In general, aqueous alcohol ( $80 \%$ methanol and $70 \%$ ethanol) are the most preferred solvents to extract phenolic compounds from plants especially herbs $[40,41]$.

Table 1 shows the yield of extracts/fractions and their respective total phenolic content. The highest amount of phenolic compounds $(\mathrm{p}<0.05)$ was found in the ethyl acetate fraction which was $1.09 \pm 0.11 \mathrm{mg}$ of GAEs/g extract, followed by the crude methanol extract $(0.75 \pm$ $0.07 \mathrm{mg}$ of GAEs/g extract), water fraction $(0.61 \pm 0.02 \mathrm{mg}$ of GAEs/g extract) and hexane fraction $(0.25 \pm 0.03 \mathrm{mg}$ of GAEs/g extract). This result suggested that extraction

Table 1 Extraction yields and content of phenolic compounds in the crude and fractionated extracts of Alpinia pahangensis

\begin{tabular}{lll}
\hline Extract/fractions & $\begin{array}{l}\text { Weight of } \\
\text { extracts }(\mathbf{g})\end{array}$ & $\begin{array}{l}\text { Total phenolic } \\
\text { content }(\mathbf{m g} / \mathbf{g})\end{array}$ \\
\hline Crude methanol & 31.19 & $0.75 \pm 0.07^{\mathrm{c}}$ \\
Hexane & 1.87 & $0.25 \pm 0.03^{\mathrm{a}}$ \\
Ethyl acetate & 2.70 & $1.09 \pm 0.11^{\mathrm{d}}$ \\
Water & 24.43 & $0.61 \pm 0.02^{\mathrm{b}}$ \\
\hline
\end{tabular}

Values expressed are mean \pm SD of triplicate measurements. Means with different letters $(a-d)$ in the same column are significantly different $(p<0.05)$. $\mathrm{mg} / \mathrm{g}: \mathrm{mg}$ of gallic acid equivalents/g of extract or fractions. using polar solvents resulted in a higher content of phenolic compounds than those using solvent with low polarity.

\section{Determination of DPPH radical scavenging activity}

This method has been widely used to evaluate the radical scavenging ability of the plant extracts as it is simple and highly sensitive. DPPH, a nitrogen-centered radical with a maximum absorption at $520 \mathrm{~nm}$ accepts an electron from an antioxidant which acts as a hydrogen donor. The scavenging activity of the extract was monitored based on the amount of DPPH radicals remaining in the test sample using a spectrophotometer. In our study, the highest scavenging effect was observed in the ethyl acetate fraction with an $\mathrm{IC}_{50}$ of $0.349 \pm 0.009 \mathrm{mg} / \mathrm{ml}$. This is followed by the crude methanol extract $(0.579 \pm$ $0.017 \mathrm{mg} / \mathrm{ml})$, water fraction $(0.999 \pm 0.038 \mathrm{mg} / \mathrm{ml})$ and hexane fraction $(2.677 \pm 0.094 \mathrm{mg} / \mathrm{ml})$. However, BHA and ascorbic acid exhibited better scavenging ability than the ethyl acetate fraction. Table 2 shows the $\mathrm{IC}_{50}$ values of the crude extract and its fractions as compared to the standards, BHA and ascorbic acid.

\section{Determination of reducing power}

Figure 1 shows the reductive ability of the crude and fractionated extracts of the rhizomes of $A$. pahangensis in comparison to $\mathrm{BHA}$ and ascorbic acid. Reductive ability was measured by the reduction of ferricyanide complex $/ \mathrm{Fe}^{3+}$ to the ferrous form $\left(\mathrm{Fe}^{2+}\right)$ in the presence of antioxidant (reductant). The $\mathrm{Fe}^{2+}$ formation produce Perl's Prussian blue and can be monitored at absorbance of $620 \mathrm{~nm}$ by a spectrophotometer. The reductive capability of the extracts and the standard compounds increased in the following order: water $<$ hexane $<$ ethyl acetate $<$ methanol $<\mathrm{BHA}<$ ascorbic acid. The reducing power of the extract increased with the increase in concentration of the extract until it reaches a certain level and then become constant. Basically, reducing power is

Table 2 Radical scavenging activity of the crude and fractionated extracts of Alpinia pahangensis against DPPH radical

\begin{tabular}{ll}
\hline Extracts and standards & $\mathbf{I C}_{\mathbf{5 0}}$ values $(\mathbf{m g} / \mathbf{m l})$ \\
\hline Crude methanol & $0.579 \pm 0.017^{\mathrm{c}}$ \\
Hexane & $2.677 \pm 0.094^{\mathrm{e}}$ \\
Ethyl acetate & $0.349 \pm 0.009^{\mathrm{b}}$ \\
Water & $0.999 \pm 0.038^{\mathrm{d}}$ \\
Ascorbic acid & $0.015 \pm 0.600^{\mathrm{a}}$ \\
BHA & $0.013 \pm 0.600^{\mathrm{a}}$
\end{tabular}

$\mathrm{IC}_{50}$ values expressed are mean \pm standard deviation of triplicate measurements. Means with different letters (a-e) in the same column are significantly different $(p<0.05)$. BHA and Ascorbic acid were used as standards. 


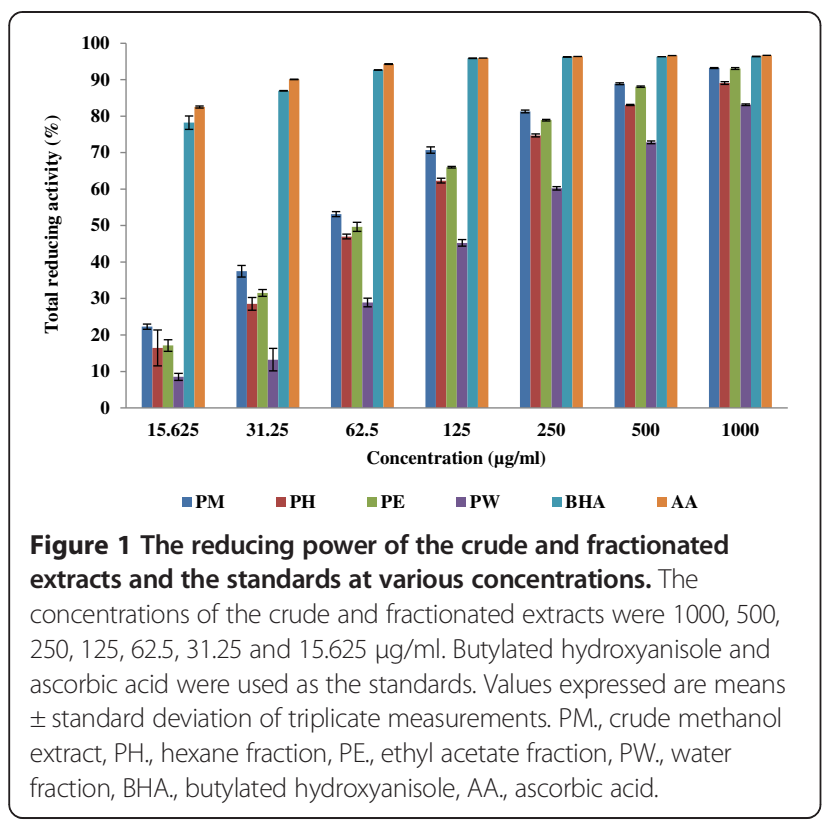

associated with the presence of reductones that break the free radical chain by donating a hydrogen atom [42].

\section{$\beta$-carotene linoleate model system}

Bleaching of $\beta$-carotene of the crude and fractionated extracts was assessed by the $\beta$-carotene-linoleate method based on Cheung et al. In this system, linoleic acid undergoes oxidation and produce hydroperoxides at $50^{\circ} \mathrm{C}$ in the presence of oxygen. In the absence of antioxidants, the hydroperoxides formed upon abstraction of a hydrogen atom from one of its diallylic methylene groups reacts with unsaturated $\beta$-carotene molecules to form a stable radical. As a result, $\beta$-carotene becomes oxidized and loses its chromophore (orange color) in the system [43,44]. However, the presence of antioxidants can hinder the extent of $\beta$-carotene bleaching by neutralizing the linoleatefree radical and other free radicals formed in the system [45]. Therefore, the antioxidant activity was measured based on reduction of the orange color which was the amount of $\beta$-carotene present in the testing solution. The level of bleaching of color of a test solution was monitored at $470 \mathrm{~nm}$. The antioxidant activities of the extracts varied significantly with different concentration of extracts $(\mathrm{p}<0.05$, Table 3$)$. The antioxidant activity of the extract and its fractions and the standard compound increased in the following order: hexane fraction $<$ water fraction $<$ ethyl acetate fraction $<$ methanol extract $<$ BHA at every concentration. The antioxidant activity of the extract and its fractions increased with an increasing concentration of the extract as shown in Table 3. The crude methanol extract exhibited $81.21 \pm 0.9 \%$ of antioxidant activity at $20 \mathrm{mg} / \mathrm{ml}$, which was comparable to that of BHA at $4 \mathrm{mg} / \mathrm{ml}(81.51 \pm 0.67 \%$, Table 3$)$.

\section{Superoxide anion scavenging activity}

The superoxide anion scavenging ability of the extracts was determined using SOD assay kit-WST. Superoxide dismutase (SOD) is an enzymatic antioxidant that can scavenge superoxide anion radical $\left(\mathrm{O}_{2}^{-}\right)$by catalyzing the dismutation of the superoxide anion into hydrogen peroxide and molecular oxygen. This assay is based on the measurement of superoxide dismutase inhibition activity. In this assay, the superoxide anion reduce WST-1 (2-(4-iodophenyl)-3-(4-nitrophenyl)-5-(2.4-disulfophenyl)$2 \mathrm{H}$-tetrazolium) to generate the water-soluble formazan dye in the testing solution, which is measured spectrophotometrically at $450 \mathrm{~nm}$. In the presence of an enzymatic antioxidant, the reduction of WST-1 can be inhibited by neutralizing $\mathrm{O}_{2}^{-}$. Thus, the SOD activity can be quantified by measuring the decrease in the color development at $450 \mathrm{~nm}$. The results in Table 4 show that the ethyl acetate fraction exhibited the highest superoxide anion scavenging ability with inhibition rate of $51.74 \pm 4.9 \%$ among all extracts and fractions. This is followed by hexane fraction $(32.21 \pm 6.5 \%)$, methanol extract (29.32 \pm $4.5 \%)$ and water fraction $(18.06 \pm 4.6 \%)$.

In summary, the crude and fractionated extracts of rhizomes of Alpinia pahangensis showed varying antioxidant properties in the entire in vitro antioxidant assays. The ethyl acetate fraction showed the greatest free radical quenching activity and superoxide anion scavenging activity associated with the highest amount of phenolic content. Thus, this shows that the phenolic

Table 3 Antioxidant activity (\%) of crude and fractionated extracts at various concentrations assayed by $\beta$-carotene bleaching assay

\begin{tabular}{llllll}
\hline Concentrations $(\mathbf{m g} / \mathbf{m l})$ & \multicolumn{4}{l}{ Antioxidant activity of crude methanol extract and its fractions } & \\
\cline { 2 - 5 } & Methanol extract & Hexane fraction & Ethyl acetate fraction & Water fraction & BHA \\
\hline $\mathbf{4}$ & $66.06 \pm 0.63^{\mathrm{dw}}$ & $23.92 \pm 4.46^{\mathrm{aw}}$ & $59.64 \pm 1.44^{\mathrm{cw}}$ & $50.03 \pm 2.67^{\mathrm{bw}}$ & $81.51 \pm 0.67^{\mathrm{ew}}$ \\
$\mathbf{8}$ & $74.73 \pm 1.84^{\mathrm{cx}}$ & $42.17 \pm 3.41^{\mathrm{ax}}$ & $72.35 \pm 2.30^{\mathrm{cx}}$ & $57.54 \pm 1.83^{\mathrm{bx}}$ & $84.50 \pm 0.21^{\mathrm{dx}}$ \\
$\mathbf{1 6}$ & $77.84 \pm 0.41^{\mathrm{cy}}$ & $52.62 \pm 2.21^{\mathrm{ay}}$ & $72.87 \pm 1.73^{\mathrm{bx}}$ & $71.74 \pm 1.80^{\mathrm{by}}$ & $89.54 \pm 0.27^{\mathrm{dy}}$ \\
$\mathbf{2 0}$ & $81.21 \pm 0.91^{\mathrm{cz}}$ & $56.80 \pm 2.70^{\mathrm{ay}}$ & $74.51 \pm 0.53^{\mathrm{bx}}$ & $74.79 \pm 1.56^{\mathrm{by}}$ & $92.92 \pm 0.23^{\mathrm{dz}}$ \\
\hline
\end{tabular}

Values expressed are mean \pm standard deviation of triplicate measurements. For the same extract or standard with different concentrations, means in the same column with different letters $(w-z)$ were significantly different $(p<0.05$, ANOVA). For different extracts with the same concentration, means in the same row with different letters (a-e) were significantly different $(p<0.05$, ANOVA). BHA was used as the standard. 


\begin{tabular}{|c|c|}
\hline Extract/fractions & Inhibiton rate (\%) \\
\hline Methanol & $29.32 \pm 4.5^{b}$ \\
\hline Hexane & $32.21 \pm 6.5^{b}$ \\
\hline Ethyl acetate & $51.74 \pm 4.9^{c}$ \\
\hline Water & $18.06 \pm 4.6^{\mathrm{a}}$ \\
\hline $\mathrm{BHA}$ & $70.19 \pm 2.9^{d}$ \\
\hline
\end{tabular}

Each value is expressed as mean \pm standard deviation of triplicate measurements. Means with different letters (a-d) in the same column are significantly different $(p<0.05)$. Data are expressed as percentage of inhibition of superoxide radicals.

content was positively correlated with DPPH radical scavenging activity and superoxide anion scavenging activity. As phenolic compounds have redox properties, this result is hardly surprising. The radical scavenging activity is usually related to the presence of hydroxyl substituents in aromatic rings, which contribute to their hydrogen donating activity [46]. Thus, the radical scavenging efficiency of the ethyl acetate extracts from Alpinia pahangensis might have been contributed by the phenolic constituents. However, the crude methanol extract possessed the strongest reducing activity against ferric ions and the highest antioxidant activity in the $\beta$ carotene bleaching assay. Lipid-soluble components are present in the crude methanol extract for the antioxidant activity shown in these two assays.

It was also observed that use of polar solvents like aqueous methanol and ethyl acetate resulted in the extraction of components showing good antioxidant activity whereas extracts obtained from non-polar solvents and water showed weak antioxidant activity. A wide variety of phenolic constituents has been reported in Alpinia species including flavonoids, tannins and some terpenoids. Thus, it is of interest to identify the compounds responsible for the antioxidant activity. Therefore, chemical isolation on the methanol or ethyl acetate fraction needs to be conducted to isolate the active components.

\section{In vitro neutral red cytotoxicity assay}

In vitro cytotoxicity assays are widely used for drug delivery to evaluate the biological effects of chemicals on mammalian cells. Many currently available assays measure cytotoxicity based on alterations of plasma permeability and the leakage of components into the supernatant or the uptake of dyes, by viable cells [47]. In this study, quantification of number of viable cells in the culture was based on the ability of the viable cells to uptake neutral red which was incorporated into the lysosomes of the cells. Acidified ethanol solution was then used to extract the dye from the viable cells and the absorbance of the solubilized dye was then measured [48]. According to US NCI plant screening program, the extract that gave $\mathrm{IC}_{50}$ of $20 \mu \mathrm{g} / \mathrm{ml}$ or less is considered active whilst it is $4 \mu \mathrm{g} / \mathrm{ml}$ or less for pure compound $[49,50]$.

Based on the result of the cytotoxic activity of the crude methanol and fractionated extracts (hexane, ethyl acetate and water) of Alpinia pahangensis (Table 5), the hexane fraction showed the highest cytotoxic activity with $\mathrm{IC}_{50}$ less than $20 \mu \mathrm{g} / \mathrm{ml}$ against KB, A549, Ca Ski, HCT 116 and HT-29 with the exception of MCF7. It also showed remarkable cytotoxic effect towards $\mathrm{KB}$ and HCT 116 with $\mathrm{IC}_{50}$ value of $5.8 \pm 0.1$ and $9.1 \pm 2.0 \mu \mathrm{g} / \mathrm{ml}$ respectively. However, it also showed cytotoxic effect against the normal cell, MRC- 5 with $\mathrm{IC}_{50}$ value of $17.3 \pm$ $0.5 \mu \mathrm{g} / \mathrm{ml}$. This was followed by the ethyl acetate fraction which showed strong cytotoxic activity against $\mathrm{KB}$ and HCT 16 with $\mathrm{IC}_{50}$ values of $10.2 \pm 0.3 \mu \mathrm{g} / \mathrm{ml}$ and $19.9 \pm$ $1.1 \mu \mathrm{g} / \mathrm{ml}$ respectively and moderate cytotoxic effect against other cell lines. However, the crude methanol and water fraction did not show cytotoxic effect against all cancer cell lines tested $\left(\mathrm{IC}_{50}\right.$ more than $\left.100 \mu \mathrm{g} / \mathrm{ml}\right)$. In this study, doxorubicin, a drug used for cancer chemotherapy as positive. Doxorubicin showed much higher cytotoxic activity against all the cancer cell lines tested in comparison to the hexane fraction and ethyl acetate fraction. Doxorubicin not only showed excellent cytotoxic effect against the cancer cell lines but it also showed strong cytotoxic effect against the normal cell line, MRC-5, with

Table $5 \mathrm{IC}_{50}(\mu \mathrm{g} / \mathrm{ml})$ values of crude and fractionated extracts of Alpinia pahangensis against selected cell lines

\begin{tabular}{|c|c|c|c|c|c|c|c|}
\hline \multirow[t]{2}{*}{ Extract/ fraction } & \multicolumn{7}{|c|}{ Inhibition concentration, $\mathrm{IC}_{50}(\mu \mathrm{g} / \mathrm{ml})$} \\
\hline & KB & MCF7 & A549 & Ca Ski & HCT 116 & HT-29 & MRC-5 \\
\hline Methanol & $>100$ & $>100$ & $>100$ & $>100$ & $>100$ & $>100$ & $>100$ \\
\hline Hexane & $5.8 \pm 0.1$ & $22.0 \pm 1.3$ & $16.6 \pm 0.2$ & $18.4 \pm 0.2$ & $9.1 \pm 2.0$ & $16.9 \pm 0.5$ & $17.3 \pm 0.5$ \\
\hline Ethyl acetate & $10.2 \pm 0.3$ & $50.3 \pm 0.3$ & $25.9 \pm 1.4$ & $35.3 \pm 2.0$ & $19.9 \pm 1.1$ & $38.4 \pm 0.4$ & $44.0 \pm 3.0$ \\
\hline Water & $>100$ & $>100$ & $>100$ & $>100$ & $>100$ & $>100$ & $>100$ \\
\hline Doxorubicin & $0.46 \pm 0.02$ & $0.088 \pm 0.01$ & $1.01 \pm 0.02$ & $0.31 \pm 0.10$ & $0.41 \pm 0.07$ & $0.56 \pm 0.05$ & $0.69 \pm 0.05$ \\
\hline
\end{tabular}

Each value is expressed as mean \pm standand deviation of triplicate measurements.

Data are expressed as $\mathrm{IC}_{50}$ in $\mu \mathrm{g} / \mathrm{ml}$ which is the concentration of extract requires to inhibit cell growth by $50 \%$ ). 
an $\mathrm{IC}_{50}$ value of $0.69 \pm 0.05 \mathrm{ug} / \mathrm{ml}$ which is much higher than the hexane fraction.

In the GCMS analysis, the hexane fraction showed the presence of a major component, methyl palmitate (13.67\%), and minor components such as methyl oleate (7.10\%), methyl stearate (2.35\%), 1,2-dimethyldecahydronaphthalene (3.05\%), 1,5-dimethyldecahydronaphthalene (2.98\%), 3,3,7,11-tetramethyl-tricyclo[6.3.0.0(2,4)] underc8-ene $(2.40 \%), 5$-phenylundecane $(0.82 \%)$ 6-phenyldodecane $(0.87 \%)$ and 5 -phenyldodecane (1.35\%). Sri Nurestri et al.[51] reported that a mixture of methyl palmitate, methyl oleate and methyl stearate showed strong cytotoxic effect against Ca Ski, A549, as well as the normal cell line, MRC-5, with $\mathrm{IC}_{50}$ values less than $20 \mathrm{ug} / \mathrm{ml}$. Methyl palmitate was also reported to exert cytotoxic effect on Tcell leukemia cell line (Molt-4) with an $\mathrm{IC}_{50}$ value of 2.28 $\mathrm{ug} / \mathrm{ml}$ whilst methyl stearate showed cytotoxicity to acute promyeloblastic leukemia cell line (HL-60) and Molt-4 cell line with $\mathrm{IC}_{50}$ values of 3.08 and $4.65 \mu \mathrm{g} / \mathrm{ml}$ respectively [52]. In view of the above report, it is highly probable that the toxicity shown by the hexane fraction maybe partly due to the presence of methyl palmitate, methyl oleate and methyl stearate. The cytotoxic effect might be contributed by one or a combination of two or more of these components. Cytotoxic agents may cause necrosis in cells whereby cells lose membrane integrity leading to cell lysis or induce apoptosis cell death by activating an ordered series of biochemical events [53,54].

\section{Conclusions}

This work describes for the first time the in vitro antioxidant and cytotoxic activity of the rhizomes of Alpinia pahangensis. The rhizomes showed good antioxidant capacity when evaluated against 5 antioxidant assays. The ethyl acetate fraction showed good DPPH radical scavenging and superoxide anion scavenging activities whilst the crude methanol extract possessed excellent reducing power ability almost comparable to that of the standards BHA and ascorbic acid, and good $\beta$-carotene bleaching activity. In contrast, the hexane extract showed good antiproliferative activity against $\mathrm{KB}$ and $\mathrm{Ca}$ Ski cell lines but weak antioxidant activity. It can thus be concluded that the rhizomes of Alpinia pahangensis have the potential to be used as chemopreventive and chemotherapeutic agent and consumption of these rhizomes may provide some health benefits. Further investigation on the underlying mechanism responsible for the biological activities should be attempted.

\section{Abbreviations}

DPPH: 2,2-diphenyl-1-picrylhydrazyl; SOD: Superoxide dismutase; GC-MS: Gas chromatography-mass spectrometry; DNA: Deoxyribonucleic acid GC: Guanine-cytosine; TA: Thymine-adenine; GAE: Gallic acid equivalents; BHA: Butylated hydroxyanisole; WST-1: 2-(4-iodophenyl)-3-(4-nitrophenyl)5-(2,4-disulfophenyl)-2H-tetrazolium.
Competing interests

The authors declare that they have no competing interests.

\section{Authors' contributions}

CWP was responsible for conducting the experiments, data analysis and interpretation, and preparing the manuscript. SNAM was responsible for providing the grants, conception of ideas, identification of components, and revising the manuscript. HI was responsible for providing grants, conception of ideas, collection and identification of plants, and revising the manuscript. All authors read and approved the final manuscript.

\section{Acknowledgements}

The author wish to acknowledge the Ministry of Science, Technology and Innovation (MOSTI) and the University of Malaya (UM) for financial assistance received through the following grants: MOSTI 12-02-03-2070 and PPP PS319/2010A.

Received: 10 May 2013 Accepted: 23 September 2013 Published: 1 October 2013

\section{References}

1. Victório PC: Therapeutic value of the genus Alpinia, Zingiberaceae. Rev Bras Farmacogn 2011, 21:194-201.

2. Matsuda H, Pongpiriyadacha Y, Morikawa T, Och M, Yoshikawa M: Gastroprotective effects of phenylpropanoids from the rhizomes of Alpinia galanga in rats: structural requirements and mode of action. Eur J Pharmacol 2003, 471:59-67.

3. Burkill $\mathrm{H}$ : A Dictionary of the Economic Products of the Malay Peninsula. London: Crown Agent; 1966.

4. Malek SN, Phang CW, Ibrahim H, Norhanom W, Sim KS: Phytochemical and cytotoxic investigations of Alpinia mutica rhizomes. Molecules 2011, 16:583-589.

5. Ghosh S, Rangan L: Alpinia: the gold mine of future therapeutics. 3 Biotech 2013, 3:1-13.

6. Awang K, Ibrahim H, Rosmy Syamsir D, Mohtar M, Mat Ali R, Azah Mohamad Ali N: Chemical constituents and antimicrobial activity of the leaf and rhizome oils of Alpinia pahangensis Ridl., an endemic wild ginger from peninsular Malaysia. Chem Biodivers 2011, 8:668-673.

7. Paz-Elizur T, Sevilya Z, Leitner-Dagan Y, Elinger D, Roisman LC, Livneh Z: DNA repair oxidative DNA damage in human carcinogenesis: potential application for cancer risk assessment and prevention. Cancer Lett 2008, 266:60-72.

8. Moreira P, Smith MA, Zhu X, Honda K, Lee HG, Aliev G, Perry G: Since oxidative damage is a key phenomenon in Alzheimer's disease, treatment with antioxidants seems to be a promising approach for slowing disease progression. Oxidative damage and Alzheimer's disease: are antioxidant therapies useful? Drug News Perspect 2005, 18:13-19.

9. Liu J, Mori A: Oxidative damage hypothesis of stress-associated aging acceleration: neuroprotective effects of natural and nutritional antioxidants. Res Commun Biol Psychol Psychiat Neurosci 2006, 31:103-119.

10. Naito Y, Uchiyama K, Yoshikawa T: Oxidative stress involvement in diabetic nephropathy and its prevention by astaxanthin. Oxid Stress Disease 2006, 21:235-242.

11. Jain SK: Superoxide dismutase overexpression and cellular oxidative damage in diabetes. A commentary overexpression of mitochondrial superoxide dismutase in mice protects the retina from diabetes. Free Rad Biol Med 2006, 41:1187-1190.

12. Beal MF: Mitochondria, oxidative damage, and inflammation in Parkinson's disease. Ann N Y Acad Sci 2003, 991:120-131.

13. Heinecke JW: Mechanisms of oxidative damage of low density lipoprotein in human atherosclerosis. Curr Opin Lipidol 1997, 8:268-274.

14. Halliwell B: How to characterize a biological antioxidant. Free Rad Res Commun 1990, 9:1-32.

15. Halliwell B: Antioxidants: the basic- what they are and how to evaluate them. Adv Pharmacol 1997, 38:3-20.

16. Volka M, Rhodes CJ, Moncol J, Izakovic M, Mazur M: Free radicals, metals and antioxidants in oxidative stress-induced cancer. Chem Biol Interact 2006, 160:1-40.

17. Niki E: Assessment of antioxidant capacity in vitro and vivo. Free Rad Biol Med 2010, 49:503-515. 
18. Moure A, Cruz JM, Franco D, Dominguez JM, Sineiro J, Dominguez $H$, Nunez M, Parajo JC: Natural antioxidants from residual sources. Food Chem 2001, 72:145-171.

19. Madsen HL, Bertelsen G: Spices as antioxidants. Trends Food Sci Technol 1995, 6:271-277.

20. Hazra B, Biswas S, Mandal N: Antioxidant and free radical scavenging activity of Spondias pinnata. BMC Complement Altern Med 2008, 8:63.

21. Ani V, Naidu KA: Antioxidant potential of bitter cumin (Centratherum anthelminticum (L.) Kuntze) seeds in in vitro models. BMC Complement Altern 2011, 11:40.

22. Rohman A, Riyanto S, Yuniarti N, Saputra WR, Utami R, Mulatsih W: Antioxidant activity, total phenolic and total flavonoid of extracts and fractions of red fruit (Pandanus conoidenus Lam). Int Food Res J 2010, 17:97-106.

23. Kleinsmith LJ: Principles of Cancer Biology. San Fransisco: Pearson Benjamin Cummings; 2006.

24. Herceg Z, Hainaut P: Genetic and epigenetic alterations as biomarkers for cancer detection, diagnosis and prognosis. Mol Oncol 2007, 1:26-41.

25. Reuter S, Gupta SC, Chaturvedi MM, Aggarwal BB: Oxidative stress, inflammation, and cancer: how are they linked? Free Radic Biol Med 2010, 49:1603-1616.

26. Rahman K: Studies on free radicals, antioxidants, and co-factors. Clin Interv Aging 2007, 2(2):219-236.

27. Lombardi V, Valko L, Stolc S, Valko M, Ondrejickova O, Horakova L, Placek J, Troncone A: Free radicals in rabbit spinal cord ischemia: electron spin resonance spectroscopy and correlation with SOD activity. Cell Mol Neurobiol 1998, 18:399-412

28. Lunec J, Holloway KA, Cooke MS, Faux S, Griffiths HR, Evans MD: Urinary 8-oxo-2'-deoxyguanosine: redox regulation of DNA repair in vivo? Free Rad Biol Med 2002, 33:875-885.

29. Sugimura T: Multi-step carcinogenesis: a 1992 perspective. Science 1992, 258:603-607.

30. Go VLW, Butrum RR, Wong DA: Diet, nutrition and cancer prevention: the postgenomic. Era J Nutr 2003, 133:3830-3836.

31. Murthy NS, Mathew A: Cancer epidemiology, prevention and control. Curr Sci 2004, 86:518-527.

32. Floyd RA, Carney JM: Free radical damage to protein and DNA: mechanisms involved and relevant observations on brain undergoing oxidative stress. Ann Neurol 1992, 32:22-27.

33. Phang CW, Malek SNA, Ibrahim H, Wahab NA: Antioxidant properties of crude and fractionated extracts of Alpinia mutica rhizomes and their total phenolic content. Afr J Pharm Pharacol 2011, 5:842-852.

34. Al-Saikhan MS, Howard LR, Miller JRJC: Antioxidant activity and total phenolics in different genotypes of potato (Solanum tuberosum, L.). J Food Sci 1995, 60:341-343.

35. Murugan K, Lyer W: Antioxidant and antiproliferative activities of Marine Algae, Gracilaria edulis and Enteromorpha lingulata, from Chennai Coast. Int J Cancer Res 2012, 8:15-26.

36. Borenfreund $E$, Puerner JA: A simple quantitative procedure using monolayer cultures for cytotoxicity assays (HTD/ NR-90). J Tissue Culture Meth 1984, 9:7-9.

37. Randhir R, Lin YT, Shetty K: Phenolics, their antioxidant and antimicrobial activity in dark germinated sprouts in response to peptide and phytochemical elicitors. Asia Pac J Clin Nutr 2004, 13:295-307.

38. Rice-Evans CA, Miller NJ, Paganga G: Antioxidant properties of phenolic compounds. Trends Plant Sci 1997, 2:152-159.

39. Proestos C, Boziaris IS, Nychas GJE, Komaitis M: Analysis of flavonoids and phenolics acids in Greek aromatic plants: investigation of their antioxidant capacity and antimicrobial activity. Food Chem 2006, 95:664-671.

40. Yu L, Haley S, Perret J, Harris M, Wilson J, Qian M: Free radical scavenging properties of wheat extracts. J Agric Food Chem 2002, 50:1619-1624.

41. Apak R, Güçlü K, Demirata B, Ozyürek M, Celik SE, Bektașoglu B, Berker K, Ozyurt D: omparative evaluation of various total antioxidant capacity assays applied to phenolic compounds with the CUPRAC assay. Molecules 2007, 12:14696-1547.

42. Duh PD: Antioxidant activity of burdock (Arctium lappa Linne): its scavenging effect on free radical and active oxygen. J Am Oil Chem Soc 1998, 75:455-461.

43. Kumaran A, Karunakaran RJ: Antioxidant and free radical scavenging of an aqueous extract of Coleus aromaticus. Food Chem 2006, 97:109-114
44. Moon JK, Shibamoto T: Antioxidant assays for plant and food components. J Agric Food Chem 2009, 57:1655-1666.

45. Jayaprakasha GK, Singh RP, Sakariah KK: Antioxidant activity of grape seed (Vitis vinifera) extracts on peroxidation models in vitro. Food Chem 2001, 73:285-290

46. Brand-Williams W, Cuvelier ME, Berset C: Use of free radical method to evaluate antioxidant activity. Lebensm-Wiss Technol 1995, 28:25-30.

47. Chiang LC, Chiang W, Chang MY, Ng LT, Lin CC: Antileukimic activity selected natural products in Taiwan. Am J Chin Med 2003, 31:37-46.

48. Repetto G, del Peso A, Zurita JL: Neutral red uptake assay for the estimation of cell viability/cytotoxicity. Nat Protoc 2008, 3:1125-1131.

49. Lee CC, Houghton P: Cytotoxicity of plants from Malaysia and Thailand used traditionally to treat cancer. J Ethanopharmacol 2005, 100:237-243.

50. Boik J: Natural compounds in cancer therapy. Minnesota, USA: Oregon Medical Press; 2001.

51. Sri Nurestri AM, Sim KS, Norhanom AW, Hashim Y: Phytochemical and cytotoxic investigations of Pereskia grandifolia Haw. (Cactaceae) leaves. J Biol Sci 2009, 9:488-493.

52. Takeara R, Jimenez $P C$, Wilke DV, Odorico de Moraes M, Pessoa C, Peporine Lopes N, Lopes JLC, Monteiro da Cruz Lotufo T, Costa Lotufo LV: Antileukemic effects of Didemnum psammatodes (Tunicata: Ascidiacea) constituents. Comp Biochem Physiol A Mol Integr Physiol 2008, 151:363--369.

53. Miret S, De Groene EM, Klaffke W: Comparison of in vitro assays of cellular toxicity in the human hepatic cell line HepG2. J Biomol Screen 2006, 11:184-193.

54. Syed Abd Rahman SN, Abdul Wahab N, Abd Malek SN: In vitro morphological assessment of apoptosis induced by antiproliferative constituents from the rhizomes of Curcuma zedoria. Evid Based Complement Alternat Med 2013, 2013:14.

doi:10.1186/1472-6882-13-243

Cite this article as: Phang et al:: Antioxidant potential, cytotoxic activity and total phenolic content of Alpinia pahangensis rhizomes. BMC Complementary and Alternative Medicine 2013 13:243.

\section{Submit your next manuscript to BioMed Central and take full advantage of:}

- Convenient online submission

- Thorough peer review

- No space constraints or color figure charges

- Immediate publication on acceptance

- Inclusion in PubMed, CAS, Scopus and Google Scholar

- Research which is freely available for redistribution 